\title{
Growth models and shell morphometrics of two populations of Melanoides tuberculata (Thiaridae) living in hot springs and freshwater pools
}

\author{
Ali Z. ELKARMI* and Naim S. ISMAIL \\ Department of Biological Sciences, Hashmite University, P.O. Box 330045, 13133 Zarqa, Jordan \\ *e-mail corresponding author: karmi@hu.edu.jo
}

\begin{abstract}
Two morphologically different populations of snail, Melanoides tuberculata (Muller, 1774), were observed at Azraq Oasis, Jordan. Snails at the hot spring, where water temperature is higher than ambient, looked larger than those at the pools. The purpose of this study is to find out if there are differences in morphometrics, age, and growth due to the variation in water temperature and to quantify these differences. Snails were randomly collected from both sites, measured and statistically and mathematically analyzed for age, growth, and shell morphometric. Results indicate that snails from hot spring and pools may survive for five and four years, respectively. Theoretically, snails from the hot springs may reach 56.0 and snails from the pools may reach $28.0 \mathrm{~mm}$ in length. However, observed lengths reached 30.0 and $19.6 \mathrm{~mm}$, respectively. The relationships of the shell length to shell and dry weights are curvilinear. However, the relationships of the shell length to shell width, aperture length, and aperture width are linear. There is an indication of an effect due to temperature difference on the age, growth and the morphometrics of the two populations of $\mathrm{M}$. tuberculata.
\end{abstract}

Key words: Melanoides tuberculata, Thiaridae, shell morphometrics, growth models, nonlinear models

\section{INTRODUCTION}

The prosobranch snail Melanoides tuberculata (Muller 1774) is a cosmopolitan species. It is wide spread in fresh and brackish water bodies of eastern and northern Africa (Brown 1980), south east Asia (Brandt 1974), India (Dutt \& Bali 1980), USA (Dundee \& Pain 1977), the Mediterranean region (Schutt 1983), and the Arabian Peninsula (Brown and Wright 1980). This snail acts as an intermediate host for many digenetic trematodes (Mohandas 1976; Haseeb 1984; Ismail \& Saliba 1985; Ismail et. al. 1988; Ismail 1990; Ismail \& Arif 1991). This feature has attracted the attention to study its population dynamics, and reproduction (Livshits \& Fishelson 1983; Dudgeon 1986; Ismail \& Arif 1993).

In Jordan, $M$. tuberculata infests most of water bodies, including Azraq Oasis, which is part of the Jordan's Eastern Desert. Two morphologically different populations of $M$. tuberculata were observed. One at the hot spring, where the water temperature was several degrees higher than the ambient temperature, and there was thick growth of aquatic algae, and the second at water pools of Azraq, where the water temperature is ambient and the bottom is covered with detritus. Snails at the hot spring looked larger than snails from pools. A number of studies have used allometry and growth models to study the population structure, growth modeling, and shell morphometrics of a number of snails. Ismail and Elkarmi (2006) reported on the age, growth and shell morphometrics of Monodonta dama from the Gulf of Aqaba, Elkarmi and Ismail (2006) studied the population structure and shell morphometrics of Theodoxus macri from Jordan, Grossowicz et al. (2003) examined the distribution of Melanopsis snail and Heller et al. (2002) reported on the systematics of Melanopsis from the coastal plain of Israel.

This study was thus initiated to study the effects of the difference in water temperature on the shell morphometrics, age, and growth of the two populations of Melanoides tuberculata and quantify the differences in shell morphometrics and other parameters found between the two populations of this snail.

\section{METHODS}

\subsection{Study Area}

Azraq Oasis lies in the Jordan Desert, $85 \mathrm{~km}$ east of Amman, in the northern part of the great Arabian Peninsula. It's the only area of permanent water in this region. Its water is supplied by two springs, one in North and the other is in South Azraq. Midway, there was a small hot spring. Its water temperature was estimated to be about $7^{\circ} \mathrm{C}$ degrees higher than ambient water temperature of other freshwater pools. This area is characterized by cold winters and usually very dry, hot summer, temperature may exceed $40{ }^{\circ} \mathrm{C}$ in the hot season, while it may go down up to $-10{ }^{\circ} \mathrm{C}$ during the coldest days of the year. The soil is mostly saline, sandy-loam or mud flats. Rainfall ranges from $50-100 \mathrm{~mm} / \mathrm{year}$ and the mean annual rainfall is mostly $50 \mathrm{~mm}$. Altitude is usually about 600-700 rarely exceeds that in some parts (AlEisawi 1996). There was no connection between hot spring and other pools. The government decided to close off the hot spring during spring of year 2000. Azraq freshwater pools are infested with several snail species. 
Most predominant are Melanopsis proemorsa and Melanoides tuberculata. Only M. tuberculata survived at the hot spring. A dense growth of algae was also noticed at the hot spring.

\subsection{Sampling and Analysis}

M. tuberculata snails were randomly collected by hand picking from the hot spring. Similarly, M. tuberculata snails were collected from the freshwater pools. In the laboratory, shell length, shell width, aperture length, and aperture width were measured using vernier calipers, to the nearest $0.1 \mathrm{~mm}$. The shell of snails collected from the freshwater pools $(\mathrm{N}=182)$ were separated from soft tissues and both fractions were dried to constant weight at $100{ }^{\circ} \mathrm{C}$. The dry weights of shell and soft body were weighed nearest to $1 \mathrm{mg}$. Measured snails were divided into size groups of length intervals which were estimated using histogram plots that show normal distribution of length. Normality was tested at $99 \%$ confidence level. These histograms were used to estimate the possible life span of $M$. tuberculata.

The growth in length of M. tuberculata were theoretically calculated using the Von Bertalanffy Growth Formula (VBGF) $\left(\mathrm{L}_{\mathrm{t}}=\mathrm{L}_{\infty}\left[1-\mathrm{e}^{-\mathrm{k}(\mathrm{t}-\mathrm{to})}\right]\right)$ and the Richard's
Growth Formula (RGF) $\left(\mathrm{L}_{\mathrm{t}}=\mathrm{L}_{\infty}\left[1-\mathrm{A} * \mathrm{e}^{-\mathrm{kt}}\right]\right)$ where $\mathrm{L}_{\mathrm{t}}$ is the length at age $\mathrm{t}, \mathrm{L}$ is the length at to, $\mathrm{A}$ is a constant, $\mathrm{k}$ is the growth coefficient and $\mathrm{t}_{\mathrm{o}}$ is the age at which the length is theoretically nil (Brown and Rothery, 1993). The constants $\mathrm{L}_{\infty}, \mathrm{K}, \mathrm{A}, \mathrm{t}_{\mathrm{o}}$ were calculated by using the Quasi-Newton method (Ostle \& Mensing 1975) to the age-length data. For comparison with VBGF and RGF, the observed age length data were fitted to a linear regression equation. The relationships of shell length to dry body weight and shell weight were described using a power regression equation (Ott 1984).

The relationships of the shell length to shell width, aperture length, aperture width, shell weight, dry weight, ratio of aperture width to shell width, ratio of aperture length to shell length, ratio of shell length to shell width, and to the ratio of aperture length to aperture width were studied using regression analysis.

\section{RESULTS}

\subsection{Age and Growth}

The frequency distribution of shell length of the collected M. tuberculata snails from hot springs which fits normal distribution indicates the presence of five age

Tab. 1. Observed and calculated shell lengths ( $\mathrm{mm}$ ) of various groups of Melanoides tuberculata collected from hot spring (A) and freshwater pools (B), using Von Bertalanffy's Growth Formula (VBGF), the Richard's Growth Formula (RGF), and the linear equation.

\begin{tabular}{ccccc}
\hline Age & Mean & & \\
(years) & $\begin{array}{c}\text { observed } \\
\text { length }\end{array}$ & VBGF & RGF & Linear model
\end{tabular}

\begin{tabular}{|c|c|c|c|c|c|c|c|c|c|}
\hline A & B & A & B & A & B & A & B & A & B \\
\hline 1 & 1 & 8.26 & 2.42 & 6.89 & 1.10 & 7.76 & 1.09 & 8.2 & 3.72 \\
\hline 2 & 2 & 13.45 & 4.29 & 12.95 & 6.95 & 13.36 & 7.02 & 12.97 & 7.45 \\
\hline 3 & 3 & 17.26 & 11.82 & 18.25 & 11.53 & 18.31 & 11.54 & 17.74 & 11.17 \\
\hline 4 & 4 & 21.83 & 16.31 & 22.89 & 15.11 & 22.86 & 14.98 & 22.51 & 14.89 \\
\hline 5 & & 27.92 & & 26.94 & & 26.55 & & 27.28 & \\
\hline $\mathrm{R}^{2}$ & & & & 0.977 & 0.918 & 0.983 & 0.912 & 0.990 & 0.960 \\
\hline
\end{tabular}
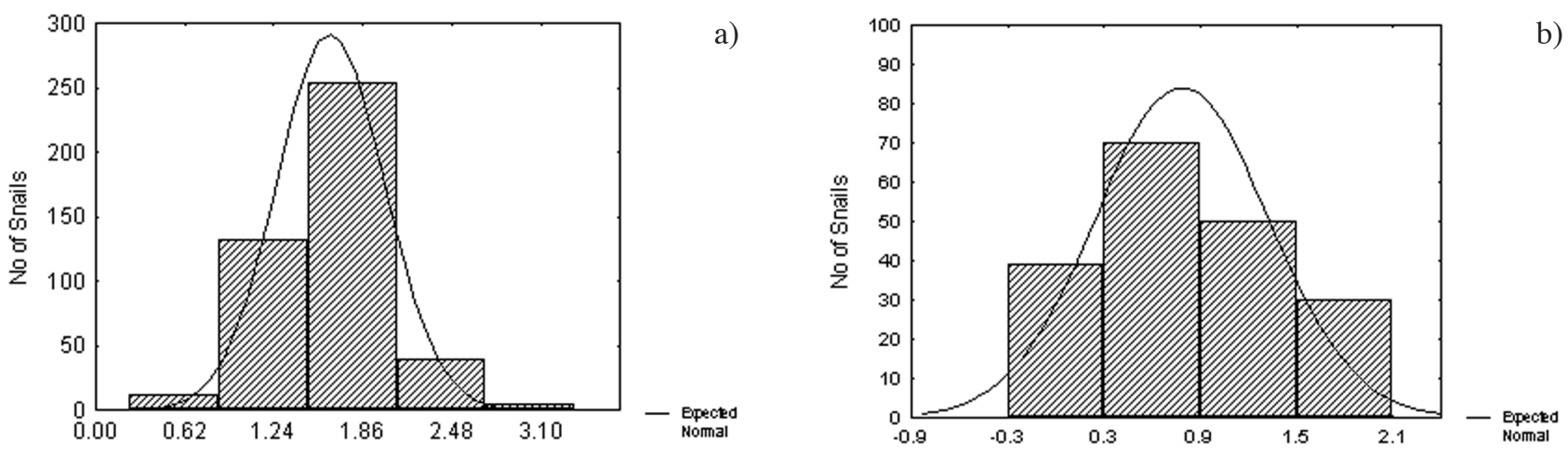

Fig. 1. (a) Frequency distribution of estimated age groups of Melanoides tuberculata from the hot spring (N=442) and (b) Frequency distribution of estimated age groups of Melanoides tuberculata from the freshwater pools $(\mathrm{N}=182)$. 
cohorts (Fig. 1), while of snails collected from freshwater pools indicates the presence of four age cohorts (Fig. 2). The mean observed length at each of these age cohorts was 8.26, 13.45, 17.26, 21.83, and $27.92 \mathrm{~mm}$, and 2.42, $4.29,11.82$, and $16.31 \mathrm{~mm}$, respectively (Tab. 1). Calculated shell length using VBGF, RGF and the linear regression were highly correlated with the observed values for both groups of snails $\left(\mathrm{R}^{2}>0.96\right)$. Thus, it is expected that snails from hot springs and freshwater pools may survive to five and four years, respectively. The annual observed increase in length ranges from 3.81 to $6.09 \mathrm{~mm}$ and from 1.87 to $6.53 \mathrm{~mm}$ for snails from hot spring and freshwater pools, respectively. However, these differences are not statistically significant $(\mathrm{P}=0.1007)$. Theoretically the increment ranges from 3.87 to $6.07 \mathrm{~mm}$ and from 3.72 to $5.85 \mathrm{~mm}$, respectively (Tab. 1). The theoretical growth parameters of $M$. tuberculata from hot springs using VBGF and RGF were similar (Tab. 2). The theoretical maximum length was 55.3 and $56.0 \mathrm{~mm}$, and growth coefficient $(\mathrm{K})$ was 0.134 and 0.123 , respectively. Likewise, theoretical growth of those from freshwater pools indicates that the maximum length may reach 28 and $26 \mathrm{~mm}$ and the $(\mathrm{K})$ was 0.245 and 0.272 , respectively (Tab. 2).
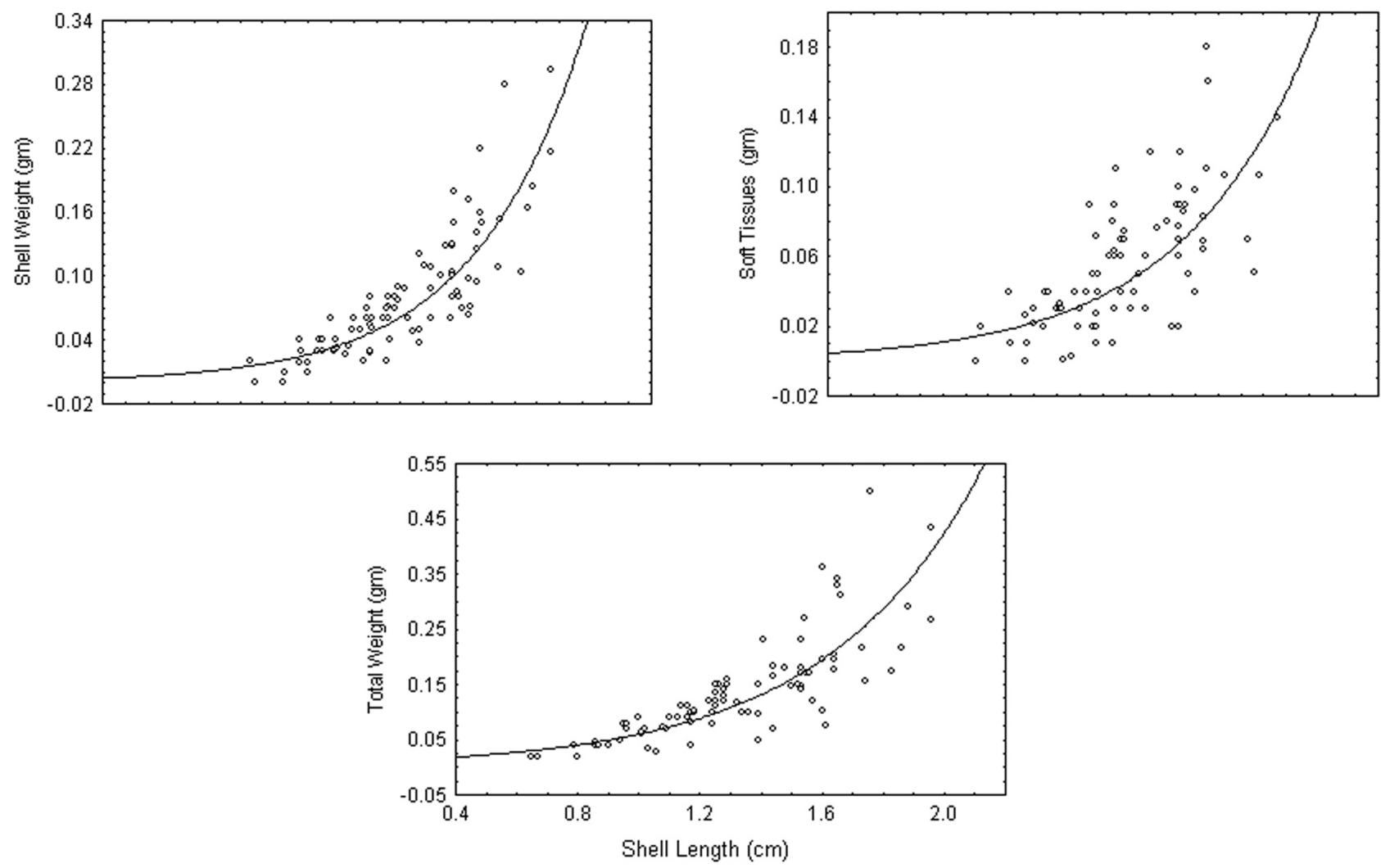

Fig. 2. The relationships of the shell length to total weight, shell weight, and soft tissues for snails from freshwater pools.

Tab. 2. Growth parameters of Melanoides tuberculata from hot spring (A) and freshwater pool (B), using Von Bertalanffy's Growth Formula (VBGF) and the Richards Growth Formula (RGF).

\begin{tabular}{crrrr}
\hline Parameter & \multicolumn{2}{c}{ VBGF } & \multicolumn{2}{c}{ RGF } \\
& \multicolumn{1}{c}{$\mathrm{A}$} & $\mathrm{B}$ & \multicolumn{1}{c}{$\mathrm{A}$} & \multicolumn{1}{c}{$\mathrm{B}$} \\
\hline $\mathrm{L}_{\infty}$ & 55.3 & 28 & 56.0 & 26 \\
$\mathrm{~K}$ & 0.134 & 0.245 & 0.123 & 0.272 \\
$\mathrm{t}_{\mathrm{o}}$ & 0.005 & 0.837 & - & - \\
$\mathrm{A}$ & - & - & 0.975 & 1.527 \\
\hline
\end{tabular}




\subsection{Length - Weight Relationships}

Collected M. tuberculata snails from hot spring ranged in length from 5.5 to $30.0 \mathrm{~mm}$, with an average of $16.3 \pm 3.7 \mathrm{~mm}$. In contrast, snails from freshwater pools range in length from 1.5 to $19.6 \mathrm{~mm}$ with an average of $7.8 \pm 5.4 \mathrm{~mm}$. Increase in shell and body weights of snails from pools was slower in young $(<13 \mathrm{~mm}$ in length) than older ones. This fact produced curvilinear relationships of the shell length to both shell and dry body weight (Fig. 3). The power regression equations for the relationships are:

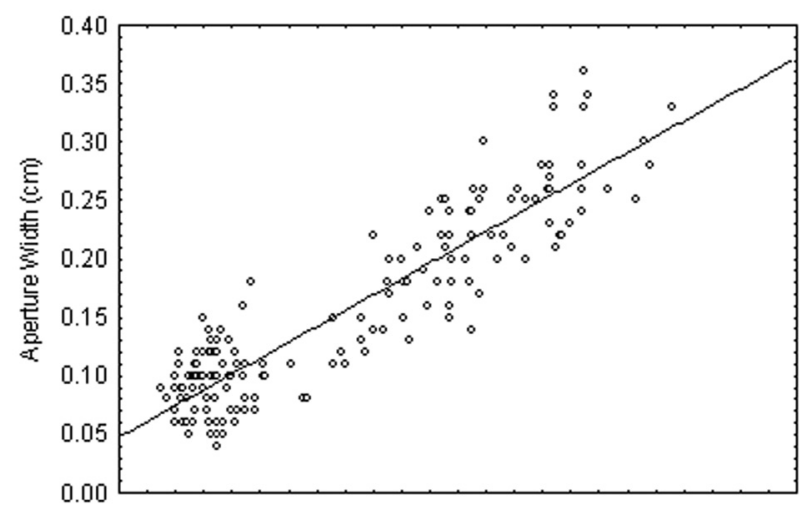

\subsection{Shell Morphometrics}

The mean shell length of age cohorts for both populations of M. tuberculata range from 8.26 to $27.92 \mathrm{~mm}$ (hot spring snails) and 2.42 to $16.31 \mathrm{~mm}$ (pools snails). The shell widths range from 2.90 to $9.88 \mathrm{~mm}$ and from 1.37 to $5.55 \mathrm{~mm}$, respectively. The aperture lengths range from 2.27 to $7.41 \mathrm{~mm}$ and from 1.14 to $4.5 \mathrm{~mm}$, respectively. The aperture width ranges from 1.35 to $4.43 \mathrm{~mm}$, and from 0.88 to $2.74 \mathrm{~mm}$, respectively. The relationships of the shell length (L) to shell width (W), aperture length (AL), and aperture width (AW) for snails

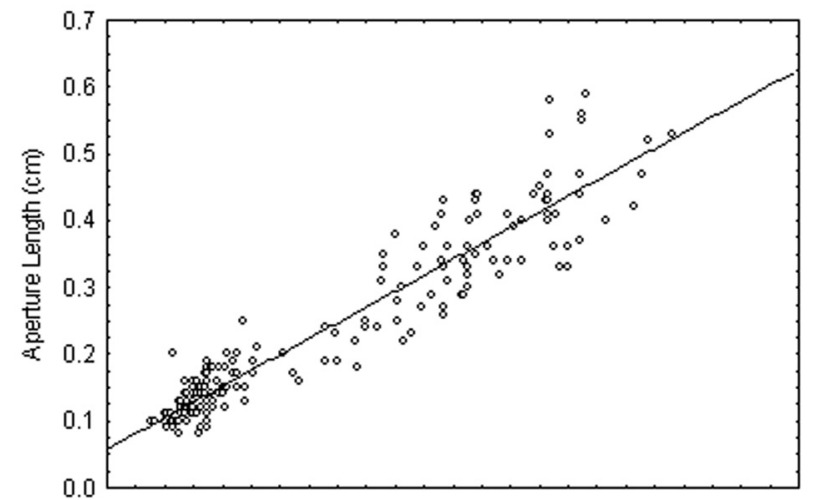

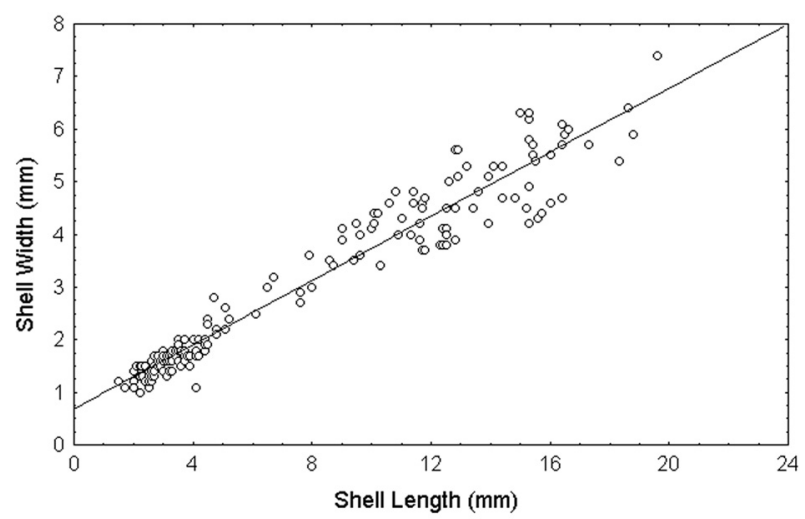

Fig. 3. The relationships of the shell length to shell width, aperture length, and aperture width of snails from freshwater pools.

$\mathrm{X}=0.193 \mathrm{~L}^{2.339}$

and

$\mathrm{X}_{1}=0.137 \mathrm{~L}^{2.481}$

Where $\mathrm{X}$ and $\mathrm{X}_{1}$ represent the shell and dry body weight, respectively, and $L$ represents shell length. No measurements were taken on shell or dry body weight for snails collected from hot spring because no live snails were found at the site after its closure by the government. from pools (Fig. 4) and hot spring (Fig. 5) are linear. The results of the regression equations are listed in tables 1 and 2.

The ratio of shell length to shell width of snails from pools increases with length, while the ratio of aperture length to shell length decreases slightly. Similarly the ratio of aperture width to shell width decreases with age. This may indicate that these snails become more elongated with age (Fig. 6). This can be inferred by comparing the slope of the straight line (0.03). The increase in 

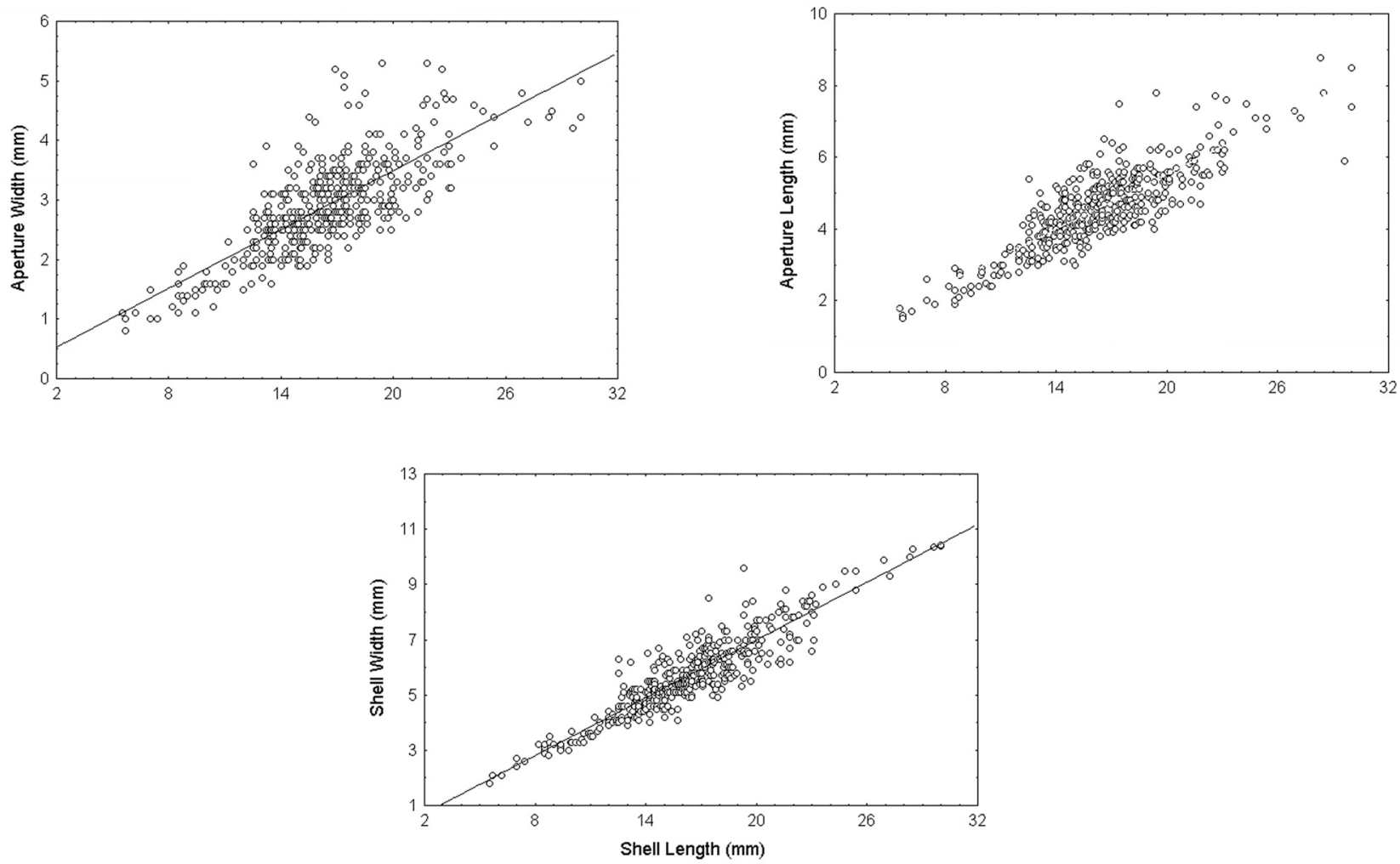

Fig. 4. The relationships of the shell length to shell width, aperture length, and aperture width of snails collected from the hot spring.
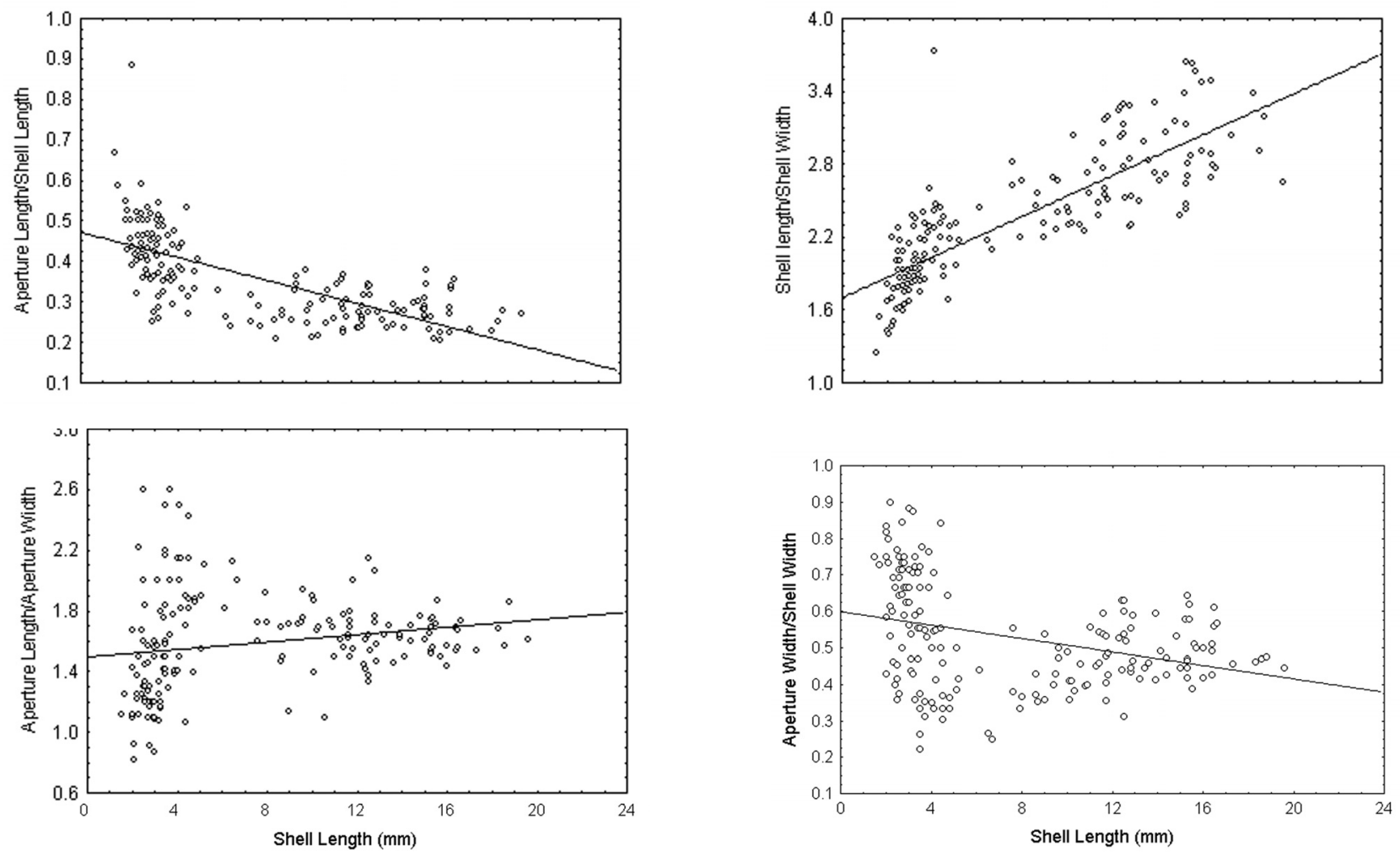

Fig. 5. The relationships of the shell length to aperture length/aperture width ratio, aperture width/shell width ratio, shell length/shell width ratio, and aperture length/shell length ratio for snails from freshwater pools. 
ratio of aperture width to width is less than increase in length since the value of the slope is less than (1.0). On the other hand, these ratios remain almost constant with age for snails from the hot spring (Fig. 7).

\section{DISCUSSION}

Results indicate that $M$. tuberculata from the hot spring and freshwater pools at Azraq may survive for five and four years, respectively. Theoretically snails may reach 56.0 and $28.0 \mathrm{~mm}$ in length, respectively. However, observed lengths reached 30.0 and $19.6 \mathrm{~mm}$, respectively. The longer $M$. tuberculata snails at the hot spring are probably due to higher water temperature and the abundance of food (algae) at the hot spring. This feature made the living conditions for these snails excellent and thus they may reach longer lengths. This phenomenon is in spite of the fact that higher temperature may increase metabolic rates and thus shorter life spans. This problem was overcome by excellent conditions at hot springs. Livshits and Fishelson (1983) reported that $M$. tuberculata snails are mainly algivorous or detrivorous. In relatively warm water at a desert spring in United Arab Emirates (29.0-31.0 $\left.{ }^{\circ} \mathrm{C}\right) \mathrm{M}$. tuberculata snails reached $26.0 \mathrm{~mm}$ in length (Ismail \& Arif 1993).
Pointier (1993) reported that $M$. tuberculata snails from the marshy forest zone of Guadeloupe, French West Indies, reached a length of $10 \mathrm{~mm}$ after 4.5 months, 15 $\mathrm{mm}$ after 14 months, and in more than 30 months they reached $20 \mathrm{~mm}$. Experimentally Livshits and Fishelson (1983) reported that $M$. tuberculata snails become fertile when reaching $15-16 \mathrm{~mm}$ at the age of six months and continued to grow to attain a maximum length of 27 $\mathrm{mm}$, at a water temperature of $26-27^{\circ} \mathrm{C}$.

Although there were differences between the two populations in length, the relationships of the shell length to shell width, aperture length, and aperture width were linear and similar regression equations were obtained. The relationship of the shell length to shell weight and body weight were curvilinear.

Ismail et al. (2000) reported that the relationships of shell length of Drupella cornus from the Gulf of Aqaba to shell width, aperture length, and aperture width were linear. However, the relationships of the shell length to shell weight and body weight were curvilinear. Similarly $M$. tuberculata snails shell lengths showed a curvilinear relationship to shell weight and body weight.
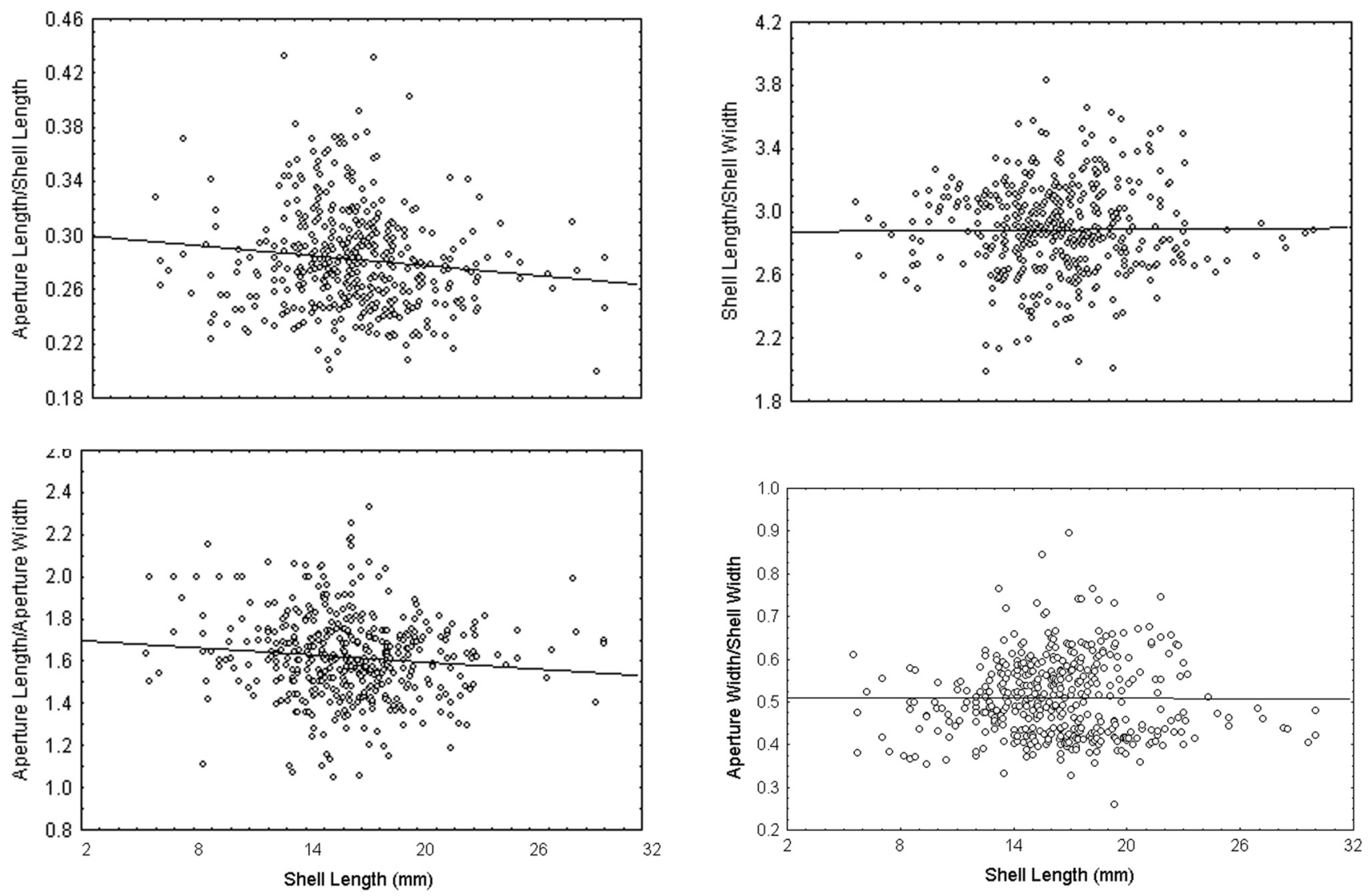

Fig. 6. The relationships of the shell length to aperture length/aperture width ratio, aperture width/shell width ratio, shell length/shell width ratio, and aperture length/shell length ratio for snails from the hot spring. 


\section{CONCLUSIONS}

There were differences between the two populations in length. This is evident in the relationships of the shell length to shell width, aperture length, and aperture width and in the relationships of the shell length to shell weight and body weight. $M$. tuberculata from the hot spring may survive for five years and M. tuberculata from the freshwater pools at Azraq may survive for four years. The rsults indicate that there are effects due to temperature difference between the hot springs and pools on the age, growth and the morphometrics of the two populations of M. tuberculata.

\section{REFERENCES}

Al-Eisawi, D. 1996. Vegetation of Jordan. UNESCO-Cairo Office: $43 \mathrm{pp}$.

Brandt, R.A.M. 1974. The non-marine aquatic Mollusca of Thailand. Arch. Molluskenk: 1-423.

Brown, D.S. 1980. Freshwater snails of Africa and their medical importance. London, Taylor and Francis: $127 \mathrm{pp}$.

Brown, D.S. \& C.A. Wright. 1980. Mollusca of Saudi Arabia: Freshwater molluscs. Fauna of Saudi Arabia, 2: 341-358.

Brown, D. \& P. Rothery. 1993. Models in Biology: Mathematics, Statistics, and Computing. New York, John Wiley \& Sons: $325 \mathrm{pp}$.

Dudgeon, D. 1986. The life cycle, population dynamics and productivity of Melanoides tuberculata (Müller, 1774) (Gastropoda: Prosobranchia: Thiaridae) in Hong Kong. $J$. Zool. Lond, 208: 37-53.

Dundee, D.S. \& A. Pain. 1977. Ecology of the snail, Melanoides tuberculata (Müller), intermediate host of the human liver fluke (Opisthorchis sinensis) in New Orleans, Louisiana. Nautilus, 91: 17-20.

Dutt, S.C. \& H.S. Bali. 1980. Snails of Punjab State and their trematode infections. J. Res. Punjab agric. Univ., 17: 222228.

Elkarmi, A. \& N. Ismail. 2006. Population structure and shell morphometrics of the gastropod Theodoxus macri (Neritidae: Prosobranchia) from Azraq Oasis, Jordan. Pak. J. Biol. Sc., 9(3): 549-552

Grossowicz, N., N. Sivan \& J. Heller. 2003. Melanopsis from the Pleistocene of the Hula Valley (Gastropoda: Cerithiodea). Isr. J. Earth Sc., 52: 221-234.

Hasseb. M.A. 1984. Studies on larval trematodes infecting freshwater snails in Pakistan. X. Non virgulate xiphidiocercaria. Z. Parasitenke, 70: 637-654.
Heller, J., N. Sivan \& F. Bea-Ami. 2002. Systematics of Melanopsis from the coastal plains of Israel (Gastropoda: Cerithiodea). J. Conchology, 37: 589-606.

Ismail, N.S. 1990. New cercaria from the freshwater snail Melanoides tuberculata in Asir Province, Saudi Arabia. Jap. J. Parasitol., 39: 172-175.

Ismail, N.S. \& E.K. Saliba. 1985. Studies on larval stages of digenetic trematodes of Melanoides tuberculata snails from Azraq Oasis, Jordan. Riv. Parasitol., 44: 263-271.

Ismail, N.S. \& A.M.S. Arif. 1991. Larval trematodes of Melanoides tuberculata (Müller, 1774) (Gastropoda: Prosobranchia) in a brackish spring, United Arab Emirates. Jap. J. Parasitol., 40: 157-169.

Ismail, N.S. \& A.M.S. Arif. 1993. Population dynamics of Melanoides tuberculata (Thiaridae) snails in a desert spring, United Arab Emirates and infection with larval trematodes. Hydrobiol., 257: 57-64.

Ismail, N.S. \& A.Z. Elkarmi. 2006. Age, Growth and Shell Morphometrics of the Gastropod Monodonta dama (Neritidae: Prosobranchia) from the Gulf of Aqaba, Red Sea. Pak. J. Biol. Sc., 9: 843-847.

Ismail, N.S., A.K. Nasher \& A.K. Al-Madani. 1988. Larval trematodes of some freshwater snails from Asir Province, Saudi Arabia. Jap. J. Parasitol., 37: 169-177.

Ismail, N.S., A.Z. Elkarmi \& S.M. Al-Moghrabi. 2000. Population structure and shell morphometrics of the corallivorous gastropod Drupella cornus (Gastropoda: Prosobranchia) in the Gulf of Aqaba, Red Sea, Indian $J$. Mar. Sci., 29: 165-170.

Livshits, G. \& L. Fishelson. 1983. Biology and reproduction of the freshwater snail Melanoides tuberculata (Gastropoda: Prosobranchia) in Israel. Isr. J. Zool., 32: 21-35.

Mohandas, A. 1976. Studies on the freshwater cercariae of Kerala V. Paramphistomatoid and Opisthorchoid cercariae. Ves Ceskoslovenske Spolecnosti Zool., XL: 196-205.

Ostle, B. \& R.W. Mensing. 1975. Statistics in Research. Third edition, Iowa, Iowa State University Press: $221 \mathrm{pp}$.

Ott, L. 1984. An Introduction to Statistical Methods and data Analysis. Second edition, Boston, Duxbury Press: 482 pp.

Pointier, J.P. 1993. Ecology of the introduced snail Melanoides tuberculata (Gastropoda, Thiaridae) in relation to Biomphalaria glabrata in the marshy forest zone of Guadeloupe, French West Indies. J. Moll. Stud., 59: 421428.

Schütt, H. 1983. Die bisher aus Jordanien bekannten süßwasser-und landbewohnenden Moousken anhand der Ausfsammlungen von Dr. Bandel 1978. Nature und Mensch: 49-64. 